\title{
Major hazard accident risk and land planning - Italian case studies: difficulties in satisfying law requirements and application to existing overexploited areas
}

\author{
A. Romano, C. Gaslini \& M. Gotti \\ TRR S.r.l., Osio Sotto (BG), Italy
}

\begin{abstract}
One of the aims of the Seveso III Directive is to grant safe and coherent land use in areas exposed to major accident risk coming from industrial plants. The rules for land use planning have been coded in the Italian Decree (May 9, 2001) having the title "Minimum safety requirements for civil and industrial land planning in area affected by major accidents risk".

The authors will analyze some substantial problems: many residential areas were built in the sixties just adjacent to industrial areas, with the aim of granting short trips for workers from home to work.

The Seveso III Directive now aims to grant safety in land planning, but it is often too late when the land is overexploited, and you have to choose between industrial and civil rights.

No new industry or change of existing installations can impose limitation in land use, which is ruled by a number of different local Authorities, each having its role and responsibility and often using different criteria for land use planning, different standards and guidelines, different ways, "languages" and time schedules to code the land use planning rules and different competences (process engineers, architects, land use managers, advocates, etc.).

All the Authorities having jurisdiction should collaborate in order to address the compatibility criteria and identify the 'sensible receptors'. A Decision Support System (DSS) has been designed in order to make all the different participants work with their competence in their "language" and manage the land use planning issues in a coherent way as a team.
\end{abstract}

Keywords: territorial planning, major hazard, accidental scenarios. 


\section{Introduction}

Article 14 of D.Lgs. 17/08/99, n.334 ("Territorial arrangement and urbanisation control" as now modified by legislative degree 238/05) aims at the definition of minimum safety requirements in land-use planning policies; this requirement recognises that planning policies can be directed towards the need for appropriate distances between industrial plants and residential areas, also the objective of preventing major accidents and limiting their consequences on settlement of new industrial plants, modification of existing plants and new developments around existing plants, such as transport links between places frequented by public and residential areas, where settlement or developments are such as to increase the risk or the consequences of a major accident.

The Italian answer to this requirements is the Ministerial Decree 9 May 2001 "Minimum Safety requirements for land-use planning policies in area involved with industrial plants with risk of major accidents hazard".

The application of this Decree requires the municipal authorities to edit the Technical Study "Major accident hazard" (RIR next). In this study the areas affected by major accident hazards, are subject to specific rules according to the level of risk and to City Planning.

\section{RIR contents according to Ministerial Decree 9 May 2001}

\section{Phase 1. Damage area}

The Municipal Authority acquires information from the administrators of plants covered by the Seveso Directive (according to laws 334/99 and 238/05), that in some cases already been submitted to the proceeding of a competent Authority.

The administrators classify scenarios representative of industrial accidents possibly arising from the hazardous activity according to the threshold values indicated in paragraph 6.2 of the Decree.

Table 1: $\quad$ Threshold values.

\begin{tabular}{|c|c|c|c|c|c|}
\hline Accident & $\begin{array}{c}\text { High } \\
\text { fatalities } \\
1\end{array}$ & $\begin{array}{c}\text { Beginning } \\
\text { fatalities } \\
2\end{array}$ & $\begin{array}{c}\text { Irreversible } \\
\text { injuries } \\
\mathbf{3}\end{array}$ & $\begin{array}{c}\text { Reversible } \\
\text { injuries } \\
4\end{array}$ & $\begin{array}{c}\text { Structural } \\
\text { damage / } \\
\text { domino } \\
\text { effects } \\
5 \\
\end{array}$ \\
\hline $\begin{array}{l}\text { Fire (stationary } \\
\text { thermal radiation) }\end{array}$ & $12,5 \mathrm{~kW} / \mathrm{m}^{2}$ & $7 \mathrm{~kW} / \mathrm{m}^{2}$ & $5 \mathrm{~kW} / \mathrm{m}^{2}$ & $3 \mathrm{~kW} / \mathrm{m}^{2}$ & $12,5 \mathrm{~kW} / \mathrm{m}^{2}$ \\
\hline $\begin{array}{l}\text { BLEVE/Fireball } \\
\text { (variable Thermal } \\
\text { radiation) }\end{array}$ & $\begin{array}{c}\text { Fireball } \\
\text { radius }\end{array}$ & $350 \mathrm{~kJ} / \mathrm{m}^{2}$ & $200 \mathrm{~kJ} / \mathrm{m}^{2}$ & $125 \mathrm{~kJ} / \mathrm{m}^{2}$ & $\underset{(*)}{200-800} \mathrm{~m}$ \\
\hline $\begin{array}{l}\text { Flash-fire (instant } \\
\text { thermal radiation) }\end{array}$ & LFL & $1 / 2 \mathrm{LFL}$ & & & \\
\hline $\begin{array}{l}\text { VCE (peak } \\
\text { overpressure) }\end{array}$ & $\begin{array}{c}0,3 \text { bar } \\
(0,6 \text { open } \\
\text { space }) \\
\end{array}$ & 0,14 bar & 0,07 bar & 0,03 bar & 0,3 bar \\
\hline $\begin{array}{l}\text { Toxic release } \\
\text { (adsorbed dose) }\end{array}$ & $\begin{array}{c}\text { LC50 } \\
\text { (30min, } \mathrm{hmn})\end{array}$ & & IDLH & & \\
\hline
\end{tabular}


Environment damage classes are defined as:

Significant damage: damage for which reclamation actions and restoring of polluted sites can be completed in two years from the beginning of actions.

- Serious damage: damage for which reclamation actions and restoring of polluted sites exceeeds two years. Serious damage represents a not environment compatibility. In order to estimate the reclamation actions and restoration of polluted sites as a result of an accident, currently makes reference to Ministerial Decree 22 October 1999, n.471 bringing "Rules criteria, procedures and modality for putting in safety, reclamation and restoring of polluted sites, according to D.Lgs. 5 February 1997, n.22 and successive modifications and integrations".

The areas of damage given from the Administrators of plants, area drawn on technical and municipal map; in particular geometric envelopes for every category of effects are drawn and for scheduled cases, the likelihood.

Phase 2. Vulnerable elements

The location and the representation of the territorial and vulnerable elements of technical and municipal cartographic supports are requested.

The analysis of territory requires one to recognize the actual conditions and the rights of the existing buildings, and also the forecasts of any future modification.

The assessment of vulnerability of territory is made according to an edification index (measure of density of residential development) and to the use of land.

It is also important to take into consideration transport, linear and local technologies, national and regional cultural assets covered by protection and safeguards. Table 2 gives territorial categories based on different criteria of mobility and possible evacuation.

Environmental vulnerable elements are:

- $\quad$ assets of landscape

- $\quad$ protected natural area

- $\quad$ superficial water resources

- deep water resources

- use of land.

\section{Phase 3. Territorial compatibility}

Assessment of territorial and environmental compatibility to determinate the right use of soil according to the presence of industrial plants.

In table 3 , criteria of compatibility between land-use and plants in every class of likelihood of the accidents are given.

We point out that the RIR must take care of integrated programs of actions on territory. In this case the study have to contain a social-economic analysis and also a technical and administrative feasibility of scheduled development.

The proposal of development of areas can define every needed action or intervention to solve complex conditions, for which it is possible to have modification to residential or industrial installation or to infrastructure also with the object of limiting the consequences of accidents. 
Table 2: $\quad$ Territorial groups.

\begin{tabular}{|c|c|}
\hline \multicolumn{2}{|c|}{ Group A } \\
\hline 1 & Mostly residential areas for which edification index is major of $4,5 \mathrm{~m}^{3} / \mathrm{m}^{2}$. \\
\hline 2 & $\begin{array}{l}\text { Places with a lot of people not able to move - for example hospital, nursing homes, homes for } \\
\text { old or young persons, elementary schools (more than } 25 \text { beds or more than } 100 \text { present } \\
\text { persons). }\end{array}$ \\
\hline 3 & Place or trading structures - for example market (more than 500 present persons). \\
\hline \multicolumn{2}{|c|}{ Group B } \\
\hline 1 & Mostly residential areas for which edification index is between 4,5 and $1,5 \mathrm{~m}^{3} / \mathrm{m}^{2}$. \\
\hline 2 & $\begin{array}{l}\text { Places with a lot of people not able to move - for example hospital, nursing homes, homes for } \\
\text { old or young persons, elementary schools. (till } 25 \text { beds or more than } 100 \text { present persons). }\end{array}$ \\
\hline 3 & Place or trading structures - for example market (till 500 present persons). \\
\hline 4 & $\begin{array}{l}\text { Crowded indoor places for example trading centres, tertiary and damager, for services, } \\
\text { secondary structures, university (more than } 500 \text { present persons). }\end{array}$ \\
\hline 5 & $\begin{array}{l}\text { Places crowded for short time of exposition to risk, places of public entertainment, for } \\
\text { recreational, sportive, cultural, religion activities (if indoors places more than } 100 \text { persons, if } \\
\text { indoor places more than } 1000 \text { persons). }\end{array}$ \\
\hline 6 & Rail stations and other transport nodes (passengers more than 100 persons/die). \\
\hline \multicolumn{2}{|c|}{ Group C } \\
\hline 1 & Mostly residential areas for which edification index is between 1,5 and $1 \mathrm{~m}^{3} / \mathrm{m}^{2}$. \\
\hline 2 & $\begin{array}{l}\text { Crowded indoor places for example trading centres, tertiary and damager, for services, } \\
\text { secondary structures, university (more than } 500 \text { present persons). }\end{array}$ \\
\hline 3 & $\begin{array}{l}\text { Places crowded for short time of exposition to risk, places of public entertainment, for } \\
\text { recreational, sportive, cultural, religion activities (if indoors places more than } 100 \text { persons, if } \\
\text { indoor places more than } 1000 \text { persons). }\end{array}$ \\
\hline 4 & Rail stations and other transport nodes (passengers more than 100 persons/die). \\
\hline \multicolumn{2}{|c|}{ Group D } \\
\hline 1 & Mostly residential areas for which edification index is between 1 and $0,5 \mathrm{~m}^{3} / \mathrm{m}^{2}$. \\
\hline 2 & $\begin{array}{l}\text { Places crowded with mouthy exposition, for example fairs, markets or other events, } \\
\text { cemeteries. }\end{array}$ \\
\hline \multicolumn{2}{|c|}{ Group E } \\
\hline 1 & Mostly residential areas for which edification index is less then $0,5 \mathrm{~m}^{3} / \mathrm{m}^{2}$. \\
\hline & Industrial, craft installation, agricultural, zoological installations. \\
\hline \multicolumn{2}{|c|}{ Group F } \\
\hline 1 & Area inside plant borderlines. \\
\hline 2 & tructures with people inside are not present \\
\hline
\end{tabular}

Table 3: $\quad$ Territorial groups compatible with effects of accidents.

\begin{tabular}{|c|c|c|c|c|}
\hline \multirow{2}{*}{$\begin{array}{c}\text { Accident probability } \\
\text { Class }\end{array}$} & \multicolumn{4}{|c|}{ EFFECTS GROUPS } \\
\cline { 2 - 5 } & $\begin{array}{c}\text { High } \\
\text { fatalities }\end{array}$ & $\begin{array}{c}\text { Beginning } \\
\text { fatalities }\end{array}$ & $\begin{array}{c}\text { Irreversible } \\
\text { injuries }\end{array}$ & $\begin{array}{c}\text { Reversible } \\
\text { injuries }\end{array}$ \\
\hline$<10^{-6}$ & $\mathrm{DEF}$ & $\mathrm{CDEF}$ & $\mathrm{BCDEF}$ & $\mathrm{ABCDEF}$ \\
\hline $10^{-4}-10^{-6}$ & $\mathrm{EF}$ & $\mathrm{DEF}$ & $\mathrm{CDEF}$ & $\mathrm{BCDEF}$ \\
\hline $10^{-3}-10^{-4}$ & $\mathrm{~F}$ & $\mathrm{EF}$ & $\mathrm{DEF}$ & $\mathrm{CDEF}$ \\
\hline$>10^{-3}$ & $\mathrm{~F}$ & $\mathrm{~F}$ & $\mathrm{EF}$ & $\mathrm{DEF}$ \\
\hline
\end{tabular}

\section{Case study of application of territorial planning decree}

Following the logic process that is explained in the previous paragraph, next a case obtained with the application of land-use planning in a Italian Municipality is explained in which there are: 
- $\quad$ seven plants with major accidents hazard;

- densely populated areas;

- $\quad$ at risk underground water resources;

- $\quad$ an important integrated program of development of land-use in different area

Phase 1. Damage area

In table 4 the list of industrial plants and the specific of application of D.Lgs. 334/99 (and next 238/05) and D.M. 471/99 are given.

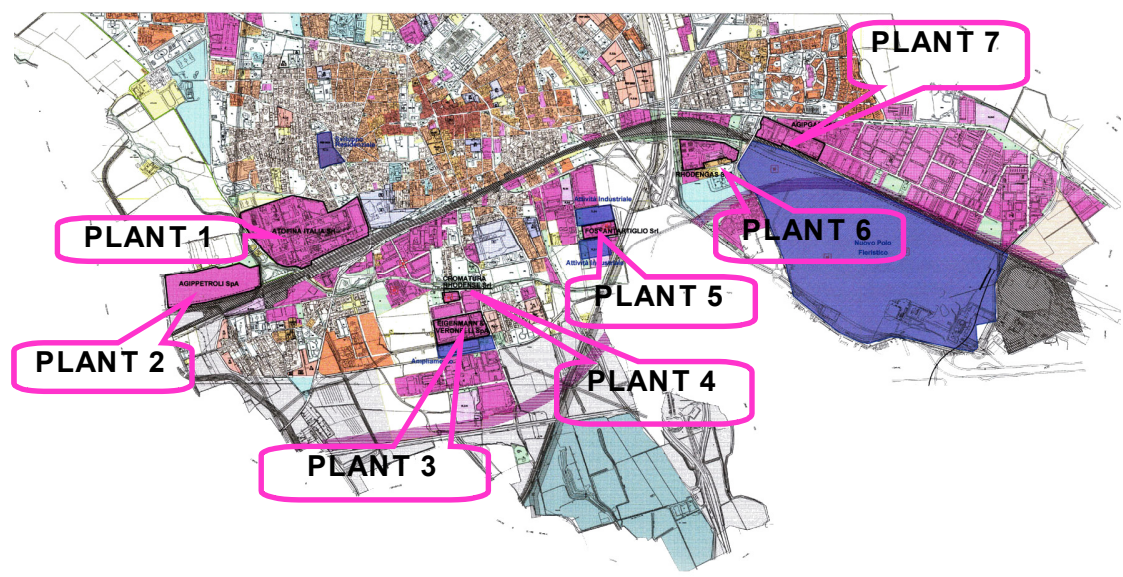

Figure 1: Territorial planning.

Table 4: $\quad$ Major accidents hazard plants involved in.

\begin{tabular}{|c|c|c|c|}
\hline Plant & Activity & $\begin{array}{c}\text { Applicability } \\
\text { D.Lgs.334/99 } \\
\text { and D.Lgs. 238/05 }\end{array}$ & $\begin{array}{c}\text { Applicability } \\
\text { D.M.471/99 }\end{array}$ \\
\hline Plant 1 & $\begin{array}{c}\text { Chemical products synthesis mostly for } \\
\text { industry and agriculture }\end{array}$ & Art.8 & NO \\
\hline Plant 2 & Flammable liquids warehouse & Art.8 & SI \\
\hline Plant 3 & Chemical products warehouse & Artt. 6 e 7 & NO \\
\hline Plant 4 & $\begin{array}{c}\text { Mechanical activity of grinding and } \\
\text { polishing and galvanic working of } \\
\text { chromium, nichel and zinc plating }\end{array}$ & Artt. 6 e 7 & SI \\
\hline Plant 5 & Zinc plating & Artt. 6 e 7 & SI \\
\hline Plant 6 & GPL warehouse & Art.8 & NO \\
\hline Plant 7 & GPL warehouse & Art.8 & NO \\
\hline
\end{tabular}

Next (table 5) information that the Administrator of Plants has sent to Ministerial Authorities about accidents and damage area evaluated is given.

Phase 2. Vulnerable elements

For each plant, vulnerable elements are pointed out inside the boundaries of the damage area, otherwise territorial groups are indicated for each threshold area. 
Table 5: $\quad$ Damage area.

\begin{tabular}{|c|c|c|c|}
\hline \multirow[t]{2}{*}{ Plant } & \multirow[t]{2}{*}{ Accidents } & Consequences & $\begin{array}{c}\text { Actual } \\
\text { compatibility }\end{array}$ \\
\hline & & Maximum diameter & \\
\hline Plant 1 & Ammonia release & $1300 \mathrm{~m}$ & $\mathrm{NO}$ \\
\hline Plant 2 & Tank fire & $180 \mathrm{~m}$ & SI \\
\hline Plant 3 & Chlorine release & $198 \mathrm{~m}$ & SI \\
\hline Plant 4 & Tetrachloroethylene pollution & $\begin{array}{c}\text { Serious environmental } \\
\text { damage }\end{array}$ & $\mathrm{NO}$ \\
\hline Plant 5 & $\begin{array}{c}\text { Chromo VI/III and Nickel } \\
\text { pollution }\end{array}$ & $\begin{array}{c}\text { Serious environmental } \\
\text { damage }\end{array}$ & NO \\
\hline Plant 6 & BLEVE & $700 \mathrm{~m}$ & $\mathrm{NO}$ \\
\hline Plant 7 & BLEVE & $970 \mathrm{~m}$ & $\mathrm{NO}$ \\
\hline
\end{tabular}

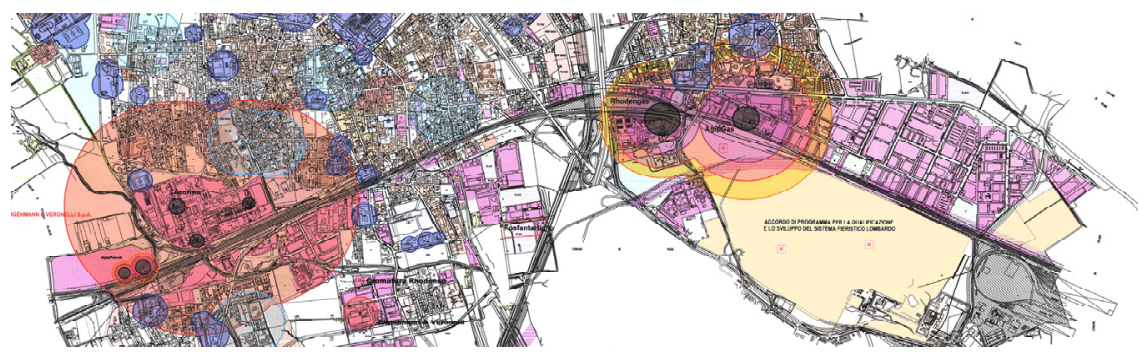

Figure 2: $\quad$ Damage area and vulnerable elements.

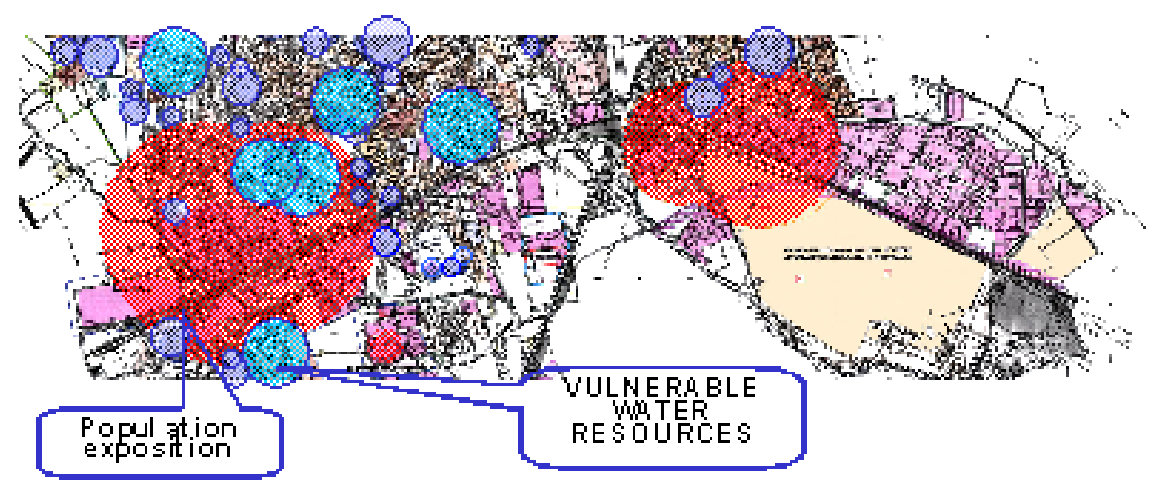

Figure 3: Damage area and vulnerable elements.

In this way it is possible to estimate the compatibility between plant and neighbouring land. above.

At the time of editing the RIR, the compatibility is represented in table 5

In figure 3, the main vulnerable elements, densely populated areas next to plants and water resources are pointed out. 
Municipal Authorities, exemplum of land-use planning, promote the editing of the RIR, also with the aims of developing a program of actions on territory implying the recovery of an industrial area. The presence of this structure involves the improvement of road and rail viability to grant access to this area. The other actions of program are:

- $\quad$ residential development near Plant 1;

- $\quad$ extension of the activity of Plant 3;

- $\quad$ industrial development near Plant 5;

Phase 3. Territorial compatibility

The land-use planning process in municipal areas makes provision for solving the non-compatibility between plants with major accident hazard, not necessarily subjected to an integrated program of scheduled development. So, taking into account actual conditions and the right of existing installations and what is near them, we proceeded to solve the incompatibility finding out the actions needed to limit the consequences of major accidents. Different types of actions are listed below.

Limiting of consequences:

Plant 1 Taking in account the residential development the company proposes plant improvements involving at first the reduction of distances corresponding to threshold value and next the limiting of consequences inside plant boundaries

Plant 6 Improvement of plant and management implying the reduction of damage areas taking into account the presence of the new exhibition installation

Plant cast-off:

Plant 7 At the same time of RIR editing, the company informs the authorities.

Solving of environmental incompatibility:

Plant 4/5 Review of reclaim Plants (according to D.Lgs. 471/99) aiming at reduction of time for putting in safety grounds

Keeping safety level:

Plant 2/3 They must grant the safety level, keeping a plant's reliability and management of its activities that can generate major accidents

In table 6 automatically damaged areas are pointed out according to limiting actions.

Table 6: Damage area after limiting actions.

\begin{tabular}{|c|c|c|}
\hline \multirow{2}{*}{ PLANT } & \multirow{2}{*}{ ACCEDENTS } & CONSEQUENCES \\
\cline { 3 - 3 } & Oleum release & Maximum diameter \\
\hline Plant 1 & Tank fire & $880 \mathrm{~m}$ \\
\hline Plant 2 & Chlorine release & $180 \mathrm{~m}$ (between borderlines) \\
\hline Plant 3 & Tetrachloroethylene pollution & Serious environmental damage \\
\hline Plant 4 & Chromo VI/III and Nickel pollution & Serious environmental damage \\
\hline Plant 5 & Fire & $80 \mathrm{~m}$ \\
\hline Plant 6 & Cast-off & -- \\
\hline Plant 7 & & \\
\hline
\end{tabular}




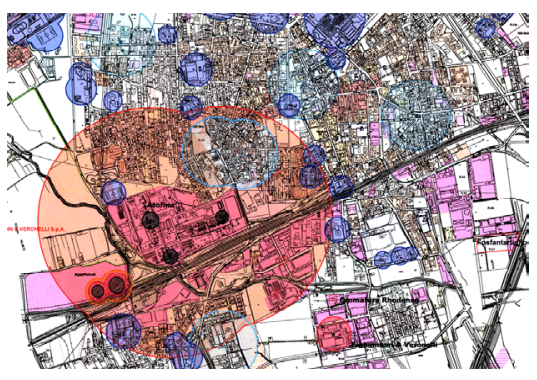

Ante

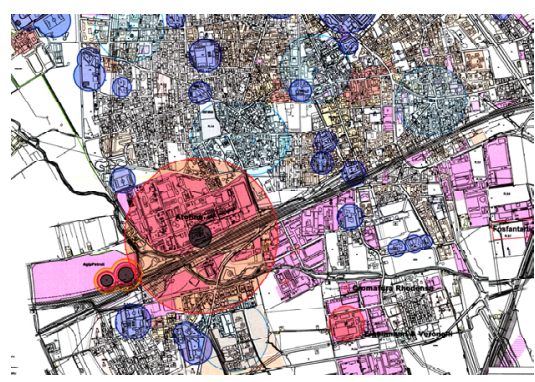

Post

Figure 4: $\quad$ Comparison between damage areas ante and post RIR (OVEST).
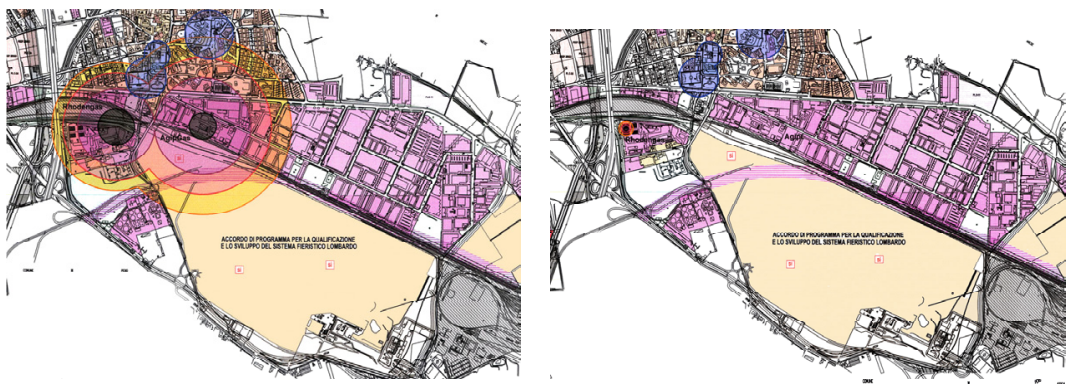

Figure 5: $\quad$ Comparison between damage areas ante and post RIR (EST).

Figures 4 and 5 carry out comparison between damage areas ante and post RIR editing.

After having restored territorial compatibility, the final phase of RIR asks one to determine edification constraints or better to determine adequate "safety distances" between plants and possible vulnerable elements.

For this reason, for each plant acceptable, territorial groups are pointed out according to new consequences.

Plant 1 area inside damage radius derived from oleum dispersion is constrained waiting reduction actions.

Plant 2: $\quad$ a safety zone (Group E) around the plant is pointed out and a gradual development of land with more vulnerable elements at major distances is expected.

Plant 3 a safety zone around the plant is pointed out (Group E) and the left a zone with vulnerable elements among the ones of Group D.

Plant 4 and 5 solving of environmental pollution.

Plant 6 a gradual development of land with more vulnerable elements at major distances is expected. 
Thereafter, the land-use planning policies must always use the criteria of inserting on territory more vulnerable elements at major distances from hazard sources.

\section{Conclusions}

Applications for the land-use planning Decree highlight for complex realities the difficulties to settle activities of plants in which there are hazardous substances with the fact that industrial plants are near or inside towns and cities. The study points out what follows:

1. The administrator of plants with risks of major accidents have to first limit the consequences of accidents in order to not imply the need for relocation and also have to evaluate the extent of consequences outside the plant's boundaries, in order to determine a safety zone around them.

2. For environmental damage, it is possible to say that in Italy reclaim plans have difficultly in working before two years, so there are incompatibility conditions with "serious damage" from plants in neighbouring territory.

3. Municipal Authorities must act according to "common sense" not only determining safety zones but also by locating vulnerable elements at major distances. As thresholds imply less risk at major distances, so more vulnerable elements (Groups A and B) must stay at major distances from hazardous sources.

4. In the case studied it refers to an integrated program of interventions among them and the realization of a crowded exhibition area implying also important improvements in road rail and rail systems approaching the area. 